\title{
Fennel (Foeniculum vulgare) and Ajwain (Trachyspermum ammi) extracts as potential preservatives in processed cheese foods
}

\author{
Syed Mansha Rafiq ${ }^{1}$ and Bikash C Ghosh ${ }^{2}$
}

Received: 31 March 2021 / Accepted: 08 April 2021 / Published online: 27 July 2021

(C) Indian Dairy Association (India) 2021

\begin{abstract}
The study was conducted to evaluate the possibility of utilization of fennel and ajwain extracts as natural preservatives in processed cheese foods. Processed cheese foods were prepared with non dairy ingredients of potato, peanuts and inulin separately and treated with fennel and ajwain extracts. The level of extract addition was optimized to $1.2 \%$ total solids and based on sensory liking, fennel extract was added into potato and inulin added cheeses and ajwain extract was added to peanut added cheese. The effect of these extracts on the sensory, physicochemical and microbiological characteristics of processed cheese foods during storage under refrigerated $\left(7-8^{\circ} \mathrm{C}\right)$ conditions was evaluated. No significant $(\mathrm{p}>0.05)$ change was observed in the sensory parameters of all the samples during storage, however the flavour was better maintained in extract added cheeses. A signiûcant $(\mathrm{p}<0.05)$ effect was observed on the tyrosine content and free fatty acids as the extract added cheeses exhibited signiûcantly $(\mathrm{p}<0.05)$ lower tyrosine and free fatty acid values. Electrophoretic study indicated lower protein degradation in spice extract added samples compared to those without extracts. A signiûcant $(\mathrm{p}<0.05)$ effect was also observed on the microbiological characteristics of the products as treated samples showed signiûcantly $(\mathrm{p}<0.05)$ lower values for yeast and mold count. Coliforms were not detected throughout the storage period. Fennel and ajwain extracts successfully improved the storage quality of processed cheese foods and may be commercially exploited as natural preservatives in cheese foods.
\end{abstract}

\footnotetext{
${ }^{1}$ National Institute of Food Technology Entrepreneurship and Management, Sonipat, Haryana 131 028, India

${ }^{2}$ Dairy Technology Section, ICAR-National Dairy Research Institute (SRS), Adugodi, Bengaluru-560 030, India

Email: ghosgoga@hotmail.com

Syed Mansha Rafiq $(\square)$

National Institute of Food Technology Entrepreneurship and Management,

Sonipat, Haryana 131028 , India

Email: mansharafiq@gmail.com
}

Keywords: Gel electrophoresis,Processed cheese; Non-dairy ingredients; Natural preservatives; Shelf life;

\section{Introduction}

Processed cheese (PC) is defined as the product produced by heating mixture of various cheese types with different degrees of ripening in the presence of appropriate emulsifying salts (Salek et al. 2015). Processed cheese foods (PCF) are prepared by adding non-dairy ingredients to the mixture (Guinee et al. 2004; Kapoor \& Metzger, 2008). Addition of non-dairy ingredients into the processed cheese might affect its keeping quality. To meet the growing market demand for cheese and cheese products it is important for the cheese-making industries to ensure the microbiological safety and stability of these products (Cusato et al. 2013; Dias et al. 2012). Therefore, to make the product shelf stable, preservatives are added. Nowadays, because of the consumer preferences for natural foods, an increased interest has been directed towards plant-based extracts as antimicrobials. Spices have been added as antimicrobials in many foods since ancient times. While substantial data exist in favour of the use of cardamom, cinnamon, clove and others as natural antimicrobials (Gyawali and Ibrahim, 2012; Hayek et al. 2013; Tajkarimi et al. 2010), interest in the antimicrobial properties of ajwain and fennel has recently emerged.

Fennel (Foeniculum vulgare) belongs to family Apiaceae. It is an indigenous herb of the Mediterranean Sea and seeds are used as spice. It contains essential oil, phenylpropanoids, monoterpenids, sesquiterpenes, coumarins, triterpenoids, tannins, flavonoids, cardiac glycosides, saponins and other types of compounds (He and Huang, 2011). Fennel seed extracts are known to possess antimicrobial activity (Abed 2007) and are reported to inhibit the growth of Curvularia lunata, Fusarium oxysporum, A. Alternate, Mucor roxuii, Bacillus cereus, Clostridium botulinum, Salmonella enteritidis, Staphylococcus aureus, Yersinia enterocolitica (Thakur et al. 2013; Prabha et al. 2002; Ceylan and Fung, 2004). Ajwain (Trachyspermum ammi) also belongs to the Apiaceae family. It is a highly valued and medicinally important seed-spice grown in Iran, India, Pakistan and Egypt. It is commonly used as a spice and a traditional medicine in India. It is reported to have antifungal/ antibacterial 
effects due to the presence of phenolic compounds thymol and carvacrol in it (Morsi 2000, Nagalakshmi et al. 2000). While the antimicrobial activity of thyme, rosemary, cinnamon, sage, cumin, clove and oregano has been reported in dairy products (Tajkarimi et al. 2010), the effect of fennel and ajwain seeds is not reported anywhere. Therefore, the objective of this study was to evaluate the effect of aqueous extracts of fennel and ajwain seeds on the shelf life of PCF.

\section{Materials and Methods}

\section{Materials}

Cheddar cheese was obtained from the dairy plant of NDRI Bengaluru. Ingredients like potatoes, peanuts, fennel, ajwain and common salt were purchased from the local market. Inulin (Frutafit HD) was obtained from M/s DKSH India Pvt. Ltd., Bengaluru. Tri-sodium citrate was used as emulsifying salt for PC preparation.

\section{Preparation of the extracts}

Fennel and ajwain seeds (250 g each) were soaked separately overnight in $200 \mathrm{~mL}$ water and ground in a grinder. During grinding additional $50-100 \mathrm{~mL}$ water was added and the contents were filtered through muslin cloth. The extracts obtained were stored in the refrigerator till its use.

\section{Manufacture of processed cheese foods}

Processed cheese and processed cheese foods were prepared according to the standardized procedure (Rafiq \& Ghosh, 2017). The prepared spice extracts were added at a level of $1.2 \%$ total solids at the end of processing so that the antimicrobial properties are not affected due to heat treatment. Based on the preliminary trial likings, fennel extract was added into the potato and inulin incorporated cheese whereas ajwain extract was added into the peanut incorporated processed cheese. The cheeses were hot packed in polypropylene cups of $150 \mathrm{~g}$ capacity, covered with aluminium laminates and kept at room temperature to cool. The cups were heat sealed after 2 hours and stored at $7-8^{\circ} \mathrm{C}$ for storage study. Samples were drawn randomly at intervals of 10 days for physico-chemical, sensory and microbiological evaluations. The samples were coded as CPC- Control processed cheese, POPotato incorporated processed cheese, PE- Peanut incorporated processed cheese, IN- Inulin incorporated processed cheese, POF- Potato incorporated processed cheese with fennel extract, PEA- Peanut incorporated processed cheese with ajwain extract, INF- Inulin incorporated processed cheese with fennel extract.

\section{Sensory evaluation}

Sensory analysis was performed on a 20-point score card according to the methodology described by Meyer (1973). Cheese slices (about $2 \mathrm{~cm}$ to $3 \mathrm{~cm}$ ) of $10 \mathrm{~g}$ to $15 \mathrm{~g}$ of each were presented in a covered glass petri plate in a random order with coded numbers. The judged parameters were: appearance (4), body and texture (8) and flavour (8). The evaluation was carried out under proper lighting by an expert panel of minimum eight judges.

\section{Physico-chemical analysis}

\section{pH}

Grated processed cheese ( $20 \mathrm{~g})$ was macerated into slurry using $20 \mathrm{~mL}$ distilled water at $40^{\circ} \mathrm{C}$. $\mathrm{pH}$ was measured directly by inserting the electrode into the slurry (Awad et al. 2005).

\section{Free fatty acids}

The free fatty acid content of the processed cheese samples was determined using BDI reagent (Deeth \& Fitz-gerald, 1976). One measure of free fatty acid is also expressed as acid degree value (Hydrolytic rancidity). Therefore, FFA/ADV is defined as the milli-equivalent of alkali $(\mathrm{KOH})$ required to neutralize the free fatty acids in $100 \mathrm{~g}$ of fat.

\section{Tyrosine value}

The proteolysis of cheese was measured in terms of soluble tyrosine by Hull methods described by Samples et al. (1984).

\section{UREA Polyacrylamide Gel Electrophoresis (PAGE)}

The protein degradation in processed cheese was measured by alkaline UREA- PAGE as per the method described by Creamer (1991).

\section{Microbiological analysis}

The microbial analyses were carried out using the methods described by Houghtby et al. (1993). Eleven grams of sample was taken in a pre-sterilized pestle and mortar mixed properly with 99 $\mathrm{ml}$ of $0.1 \%$ saline. Further dilution to the desired level was carried out by serially transferring $1 \mathrm{ml}$ of diluted sample to $9 \mathrm{ml}$ sterile saline.

\section{Yeast and Mould count}

Yeast and Mould counts were determined by plating 1, 2 dilutions of processed cheese using Potato Dextrose Agar (Hi-Media). The $\mathrm{pH}$ of the medium was adjusted to around 3.5 by adding $1 \mathrm{ml}$ of sterile tartaric acid solution (10\%) to $100 \mathrm{ml}$ of sterilized media, before pouring the media into plates. The count was taken after 3 days of incubation at $30^{\circ} \mathrm{C}$.

\section{Coliform count}

Coiform count was determined by plating $1 \mathrm{ml}$ of product suspension employing Violet Red Bile Agar (Hi-Media). Plates were incubated at $37^{\circ} \mathrm{C}$ for $24-48$ hours in duplicates. Colonies 
with dark red coloration were counted and expressed as $\mathrm{cfu} / \mathrm{g}$ of the product.

\section{Statistical analysis}

The data was compiled and analyzed using the statistical software SPSS 16.0 (Stat Soft Polska, Poland). One way analysis of variance (ANOVA) was performed and significant differences among samples were reported according to Duncan's test at $\mathrm{p}<0.05$.

\section{Results and Discussion}

Table 1 Compositional analysis of processed cheese and processed cheese foods

\begin{tabular}{|c|c|c|c|c|c|}
\hline & SAMPLES & Moisture (\%) & $\begin{array}{l}\text { Total Fat }(\%) \\
\text { Protein }(\%)\end{array}$ & Total Ash (\%) & $\begin{array}{c}\text { Total } \\
\text { Carbohydrate }(\%)\end{array}$ \\
\hline$\overline{\mathrm{CPC}}$ & $42.19 \pm 1.03^{\mathrm{a}}$ & $30.08 \pm 0.48^{b}$ & $22.58 \pm 0.74^{\mathrm{a}}$ & $4.32 \pm 0.12^{\mathrm{a}}$ & $0.58 \pm 0.05^{\mathrm{d}}$ \\
\hline PO & $44.39 \pm 0.86^{\mathrm{a}}$ & $23.74 \pm 1.05^{\mathrm{d}}$ & $18.65 \pm 0.35^{\mathrm{c}}$ & $3.65 \pm 0.25^{\mathrm{b}}$ & $8.74 \pm 0.94^{\mathrm{a}}$ \\
\hline $\mathrm{PE}$ & $42.13 \pm 0.63^{\mathrm{a}}$ & $31.82 \pm 0.72^{\mathrm{a}}$ & $20.96 \pm 0.88^{\mathrm{a}}$ & $3.74 \pm 0.23^{\mathrm{b}}$ & $2.08 \pm 0.42^{\mathrm{c}}$ \\
\hline $\mathbb{N}$ & $39.61 \pm 0.71^{\mathrm{ab}}$ & $27.09 \pm 0.55^{\mathrm{c}}$ & $20.34 \pm 00.49^{c}$ & $3.89 \pm 0.14^{\mathrm{b}}$ & $6.94 \pm 0.32^{\mathrm{b}}$ \\
\hline POF & $44.07 \pm 0.78^{a}$ & $22.44 \pm 0.85^{\mathrm{d}}$ & $19.37 \pm 0.55^{\mathrm{c}}$ & $3.53 \pm 0.22^{\mathrm{b}}$ & $8.23 \pm 0.48^{\mathrm{a}}$ \\
\hline
\end{tabular}

The results are expressed as mean \pm standard deviation $(n=6)$; means with different superscripts in a row differ significantly $(\mathrm{p}<0.05)$. CPC-Control processed cheese, PO- Potato incorporated processed cheese, PE- Peanut incorporated processed cheese, IN- Inulin incorporated processed cheese, POF- Potato incorporated processed cheese with fennel extract, PEA- Peanut incorporated processed cheese with ajwain extract, INF- Inulin incorporated processed cheese with fennel extract.

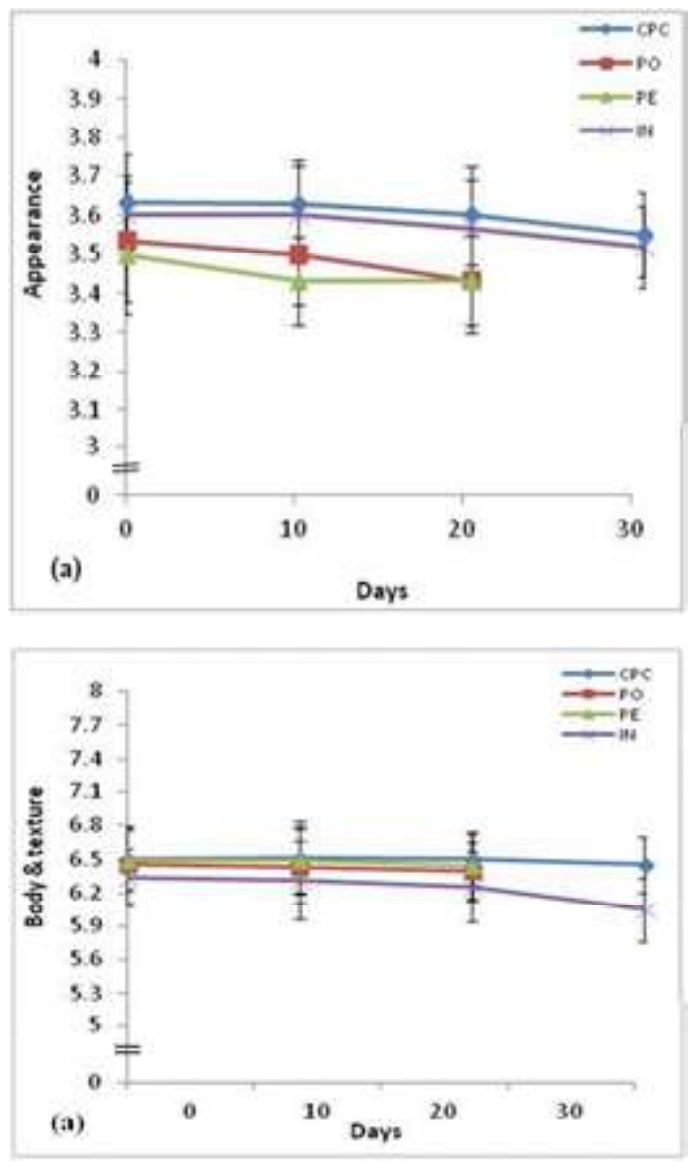



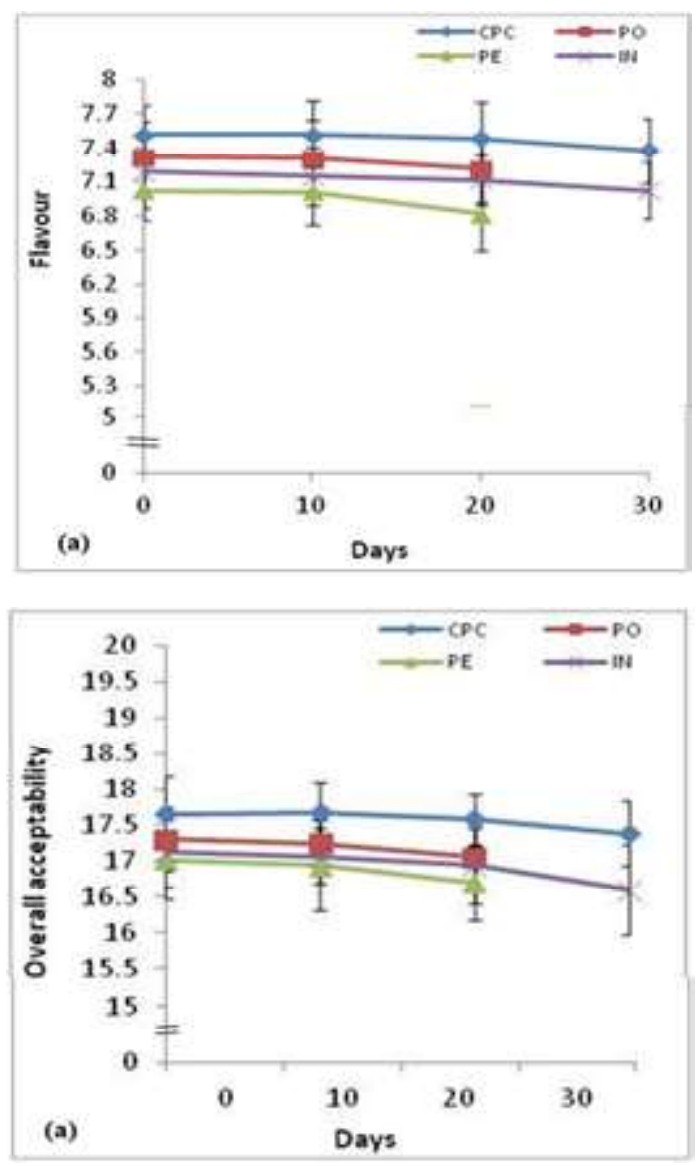
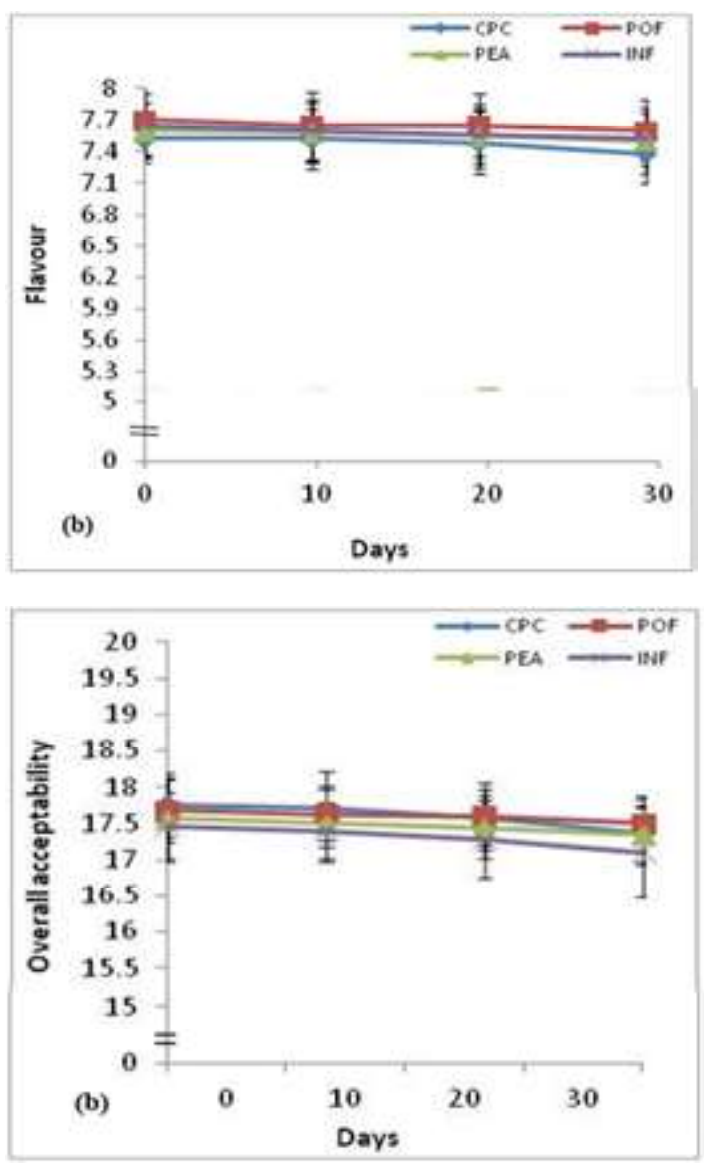

Fig. 1 Effect of non dairy ingredients on: (A) appearance, (B) body \&texture, (C) flavour and (D) overall acceptability of processed cheese during storage; (a) Without spice extracts, (b) With spice extracts; CPC-Control processed cheese, PO- Potato incorporated processed cheese, PE- Peanut incorporated processed cheese, IN- Inulin incorporated processed cheese, POF- Potato incorporated processed cheese with fennel extract, PEA- Peanut incorporated processed cheese with ajwain extract, INF- Inulin incorporated processed cheese with fennel extract.

extracts which imparted slight green and brown colour respectively to the treated cheese samples. However, during storage no significant change $(p>0.05)$ was observed in appearance score among the cheese samples irrespective of treatments. The initial body and texture scores were lowest in IN both with and without fennel extract compared to control and other treated samples however, no significant difference $(\mathrm{p}>$ 0.05 ) was found among the samples. The lowest scores in IN might be because inulin which is a soluble fibre resulted in decrease in moisture and fat content (Table 1) and the cheese appeared to be dry and firm compared to other samples and was not liked much by the panellists. As the storage progressed the body and texture scores decreased in all the samples but no significant difference $(\mathrm{p}>0.05)$ was observed between the samples.

The initial flavour scores of PCFs were slightly lower than the control. It was observed that during storage there was no significant change $(p>0.05)$ in the flavour score of all the cheese samples irrespective of different treatments. However, at $20^{\text {th }}$ day of storage, a slight decrease was observed in the flavour score of PO and PE compared to control. The decrease in the flavour scores of potato and peanut incorporated cheese might be due to the increased proteolysis and lipolysis as evident from Figure $2 \mathrm{~B}$ and $2 \mathrm{C}$ which produced slight acid and rancid flavours respectively. This could be due to the increased microbial activity in these samples because of high carbohydrate and moisture content (Table 1) providing favourable condition for the rapid microbial activity. Addition of spice extracts into PCFs improved the flavour and resultant cheeses showed higher initial flavour scores than those without spice extracts. During storage no significant change $(p>0.05)$ was observed in the flavour score of spice extract added cheese samples compared to those without spice extracts and control. Moreover, the flavour was better maintained during storage contributing to its acceptability. The overall acceptability scores of the cheese samples with spice extracts were higher as compared to those without any added extracts both initially as well as towards the end of storage 
however, no significant difference $(\mathrm{p}>0.05)$ was found among the samples. The higher acceptability scores might be because of the higher flavour scores of extract added samples compared to those without extracts although the appearance scores were lower than those without extracts and body and texture was almost similar in all.

\section{Physicochemical analysis}

\section{Change in $\mathrm{pH}$}

The $\mathrm{pH}$ of all the cheese samples was found to increase up to the $10^{\text {th }}$ day of storage and thereafter it decreased till the end of storage in all the PCF samples without spice extracts Figure 2(a)A whereas the $\mathrm{pH}$ of the spice extract added PCF samples and control processed cheese increased till $20^{\text {th }}$ day of storage and thereafter decreased till the end of storage Figure 2(b)A. However, no significant difference $(\mathrm{p}>0.05)$ was found in $\mathrm{pH}$ among the samples during storage. Initial $\mathrm{pH}$ of 5.36 in control processed cheese increased to 5.49 on $20^{\text {th }}$ day of storage and then decreased to 5.46 on $30^{\text {th }}$ day of storage. Among the treated samples, PO showed the highest initial $\mathrm{pH}$ (5.55) followed by IN (5.45). The $\mathrm{pH}$ of IN decreased to 5.37 at $30^{\text {th }}$ day of storage. Among spice extract added samples the initial $\mathrm{pH}$ of INF was lower than POF and PEA however, at $30^{\text {th }}$ day of storage; the $\mathrm{pH}$ was similar in all the samples. The increase in the $\mathrm{pH}$ during the initial days of storage is non-significant $(\mathrm{p}>0.05)$ however; the decrease in $\mathrm{pH}$ during storage could be due to the microbial spoilage. Reduction of $\mathrm{pH}$ during storage of processed cheese has been reported previously by Hussein et al. (2011) and Renuka et al. (2016).

\section{Change in tyrosine content}

Tyrosine content, which is a measure of degree of proteolysis significantly affects the acceptability of a product. All the stored samples were analyzed for tyrosine content with a view to monitor the proteolytic changes that occured during storage. The increase in tyrosine content in PCFs without spice extracts is shown in Figure 2(a)B and those with spice extracts in Figure 2(b)B. A gradual increase in tyrosine content of all the samples, irrespective of preservative treatment, was noticed during storage. At $0^{\text {th }}$ day of storage no significant difference $(p>0.05)$ was found in the tyrosine content of the treated samples when compared to control. However, at $10^{\text {th }}$ day of storage PO showed significantly higher $(\mathrm{p}<0.05)$ tyrosine content of $1.62 \mathrm{mg} / \mathrm{g}$ compared to control $(1.47 \mathrm{mg} / \mathrm{g})$ and treated samples PE, (1.44 $\mathrm{mg} / \mathrm{g})$ and IN $(1.37 \mathrm{mg} / \mathrm{g})$. This could be due to the increased microflora in $\mathrm{PO}$ as a result of higher carbohydrate and moisture content favouring the growth of molds which might have caused more rapid proteolysis thereby increasing the amount of tyrosine as compared to control and other treated samples. At $20^{\text {th }}$ day of storage a significant increase $(p<0.05)$ in the tyrosine value of PE $(1.72 \mathrm{mg} / \mathrm{g})$ was also observed compared to CPC which is again due to the increased microflora causing more rapid proteolysis. No significant change $(p>0.05)$ was observed in the tyrosine content of IN up to $20^{\text {th }}$ day of storage however, it increased significantly to $1.76 \mathrm{mg} / \mathrm{g}$ at $30^{\text {th }}$ day of storage.

The rate of increase of tyrosine content was slightly lower in spice extract added samples than those of without extract addition. Tyrosine content of $1.63 \mathrm{mg} / \mathrm{g}$ in POF at $10^{\text {th }}$ day of storage increased to $1.79 \mathrm{mg} / \mathrm{g}$ at $20^{\text {th }}$ day of storage compared to PO wherein it increased from 1.62 at $10^{\text {th }}$ day of storage to $1.86 \mathrm{mg} / \mathrm{g}$ at $20^{\text {th }}$ day of storage however no significant difference $(\mathrm{p}>0.05)$ was found between $10^{\text {th }}$ and $20^{\text {th }}$ day of storage. Similarly PEA showed lower tyrosine content of $1.63 \mathrm{mg} / \mathrm{g}$ at $20^{\text {th }}$ day of storage as compared to PE. INF also showed a lower tyrosine content of $1.61 \mathrm{mg} / \mathrm{g}$ at $30^{\text {th }}$ day of storage as compared to $1.76 \mathrm{mg} / \mathrm{g}$ in IN. Spice extracts were found to slow down the rate of change of proteolysis in PCFs to some extent.

\section{Changes in free fatty acid (FFA) content}

Free fatty acid content of all the samples increased throughout the storage irrespective of the treatments as shown in Figure 2C. Initial FFA content of 3.04 in control processed cheese increased significantly $(\mathrm{p}<0.05)$ to 4.07 at $30^{\text {th }}$ day of storage however up to $20^{\text {th }}$ day of storage the increase in FFA content was non significant $(\mathrm{p}>0.05)$. At $20^{\text {th }}$ day of storage a significant increase $(p<0.05)$ was observed in the FFA content of PO and PE compared to control Figure 2(a)C. However, no significant increase ( $p>$ 0.05 ) was found in the FFA content of IN. The significant increase $(p<0.05)$ in the FFA content of PO could be due to the increased activity of moulds in potato added cheese which had higher moisture and higher carbohydrate content whereas, in PE it could be due to the higher fat content. At $30^{\text {th }}$ day of storage no significant increase $(p>0.05)$ was found in the FFA content of IN when compared to control.

Addition of spice extracts had a positive effect on the rate of change of lipolysis as shown in Figure $2 \mathrm{C}(\mathrm{b})$. It was found that POF and PEA did not show any significant increase $(p>0.05)$ in the FFA content compared to control however during storage however, a slight increase was observed. The rate of increase was lower in cheese samples with extracts compared to those without extracts. POF showed an FFA content of 3.25 at $20^{\text {th }}$ day of storage which was lower than $\mathrm{PO}$ which showed an FFA content of 3.83 however, no significant difference $(p>0.05)$ was found between the two cheeses. Similarly PEA showed an FFA content of 3.28 which was lower than PE which showed FFA content of 4.05 at $20^{\text {th }}$ day of storage. Similar trend was seen in INF.

\section{Proteolysis - Alkaline Urea PAGE}

The hydrolysis of proteins in processed cheese samples over a storage period of 30 days at $7-8^{\circ} \mathrm{C}$ was evaluated by alkaline urea-PAGE. Electrophoretrograms of all the cheese samples are shown in Figure 4- 6 . Protein bands were identified by comparison with standards sodium caseinate where, $\beta$ - Casein $(\beta-\mathrm{CN})$ and $\alpha$ - 

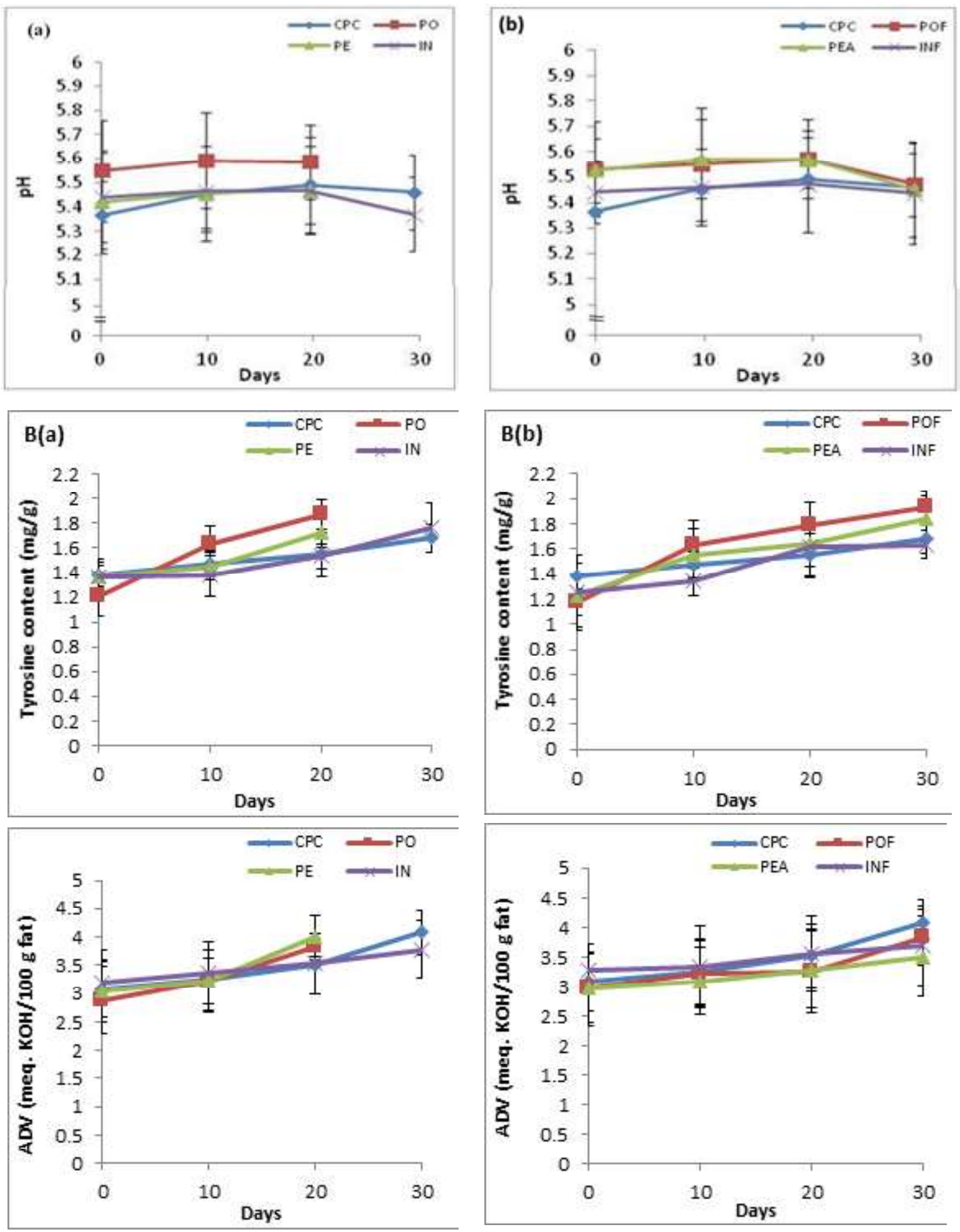

Fig. 2 Effect of non dairy ingredients on the: (A) pH, (B) Tyrosine and (C) FFA content of processed cheese during storage; (a) Without spice extracts, (b) With spice extracts; CPC- Control processed cheese, PO- Potato incorporated processed cheese, PE- Peanut incorporated processed cheese, IN- Inulin incorporated processed cheese, POF- Potato incorporated processed cheese with fennel extract, PEA- Peanut incorporated processed cheese with ajwain extract, INF- Inulin incorporated processed cheese with fennel extract. 

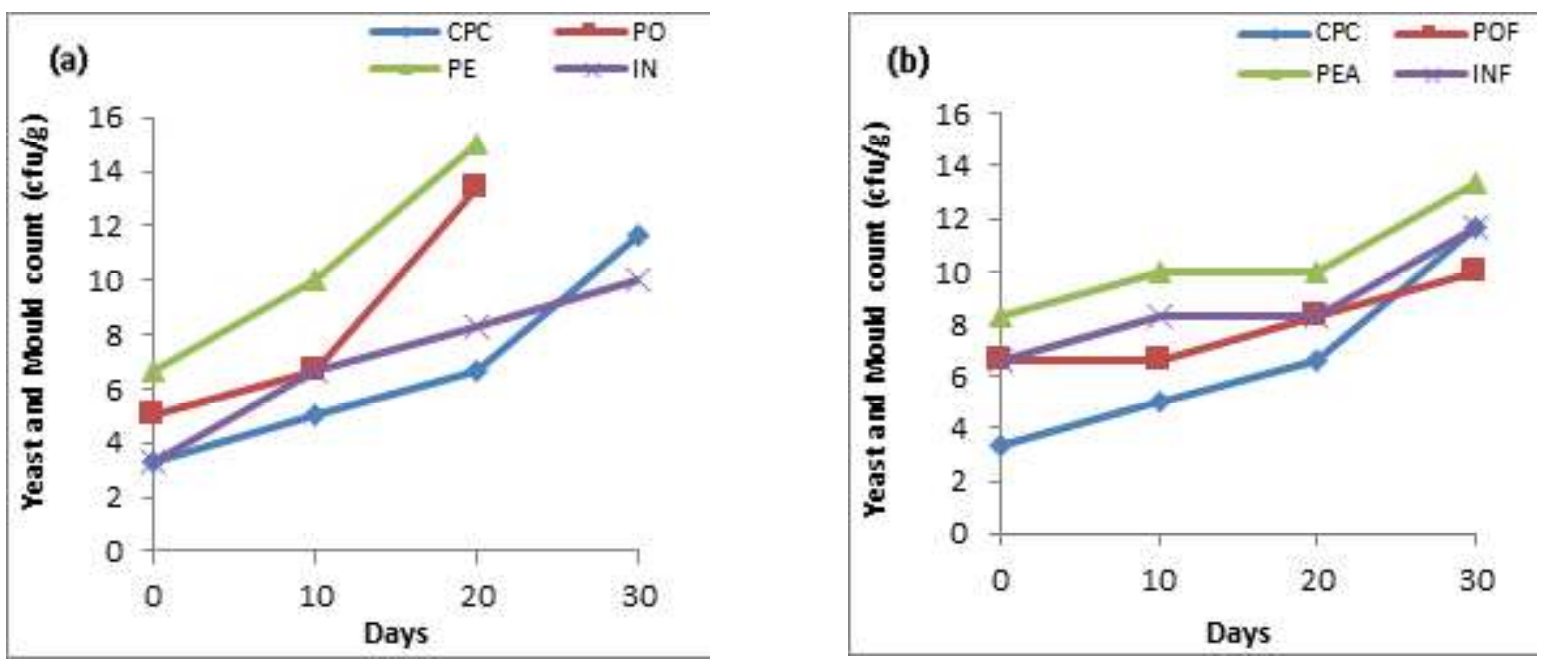

Fig. 3 Effect of non dairy ingredients on the yeast and mould count of processed cheese during storage; (a) Without spice extracts, (b) With spice extracts; CPC- Control processed cheese, PO- Potato incorporated processed cheese, PEPeanut incorporated processed cheese, IN- Inulin incorporated processed cheese, POF- Potato incorporated processed cheese with fennel extract, PEA- Peanut incorporated processed cheese with ajwain extract, INF- Inulin incorporated processed cheese with fennel extract.

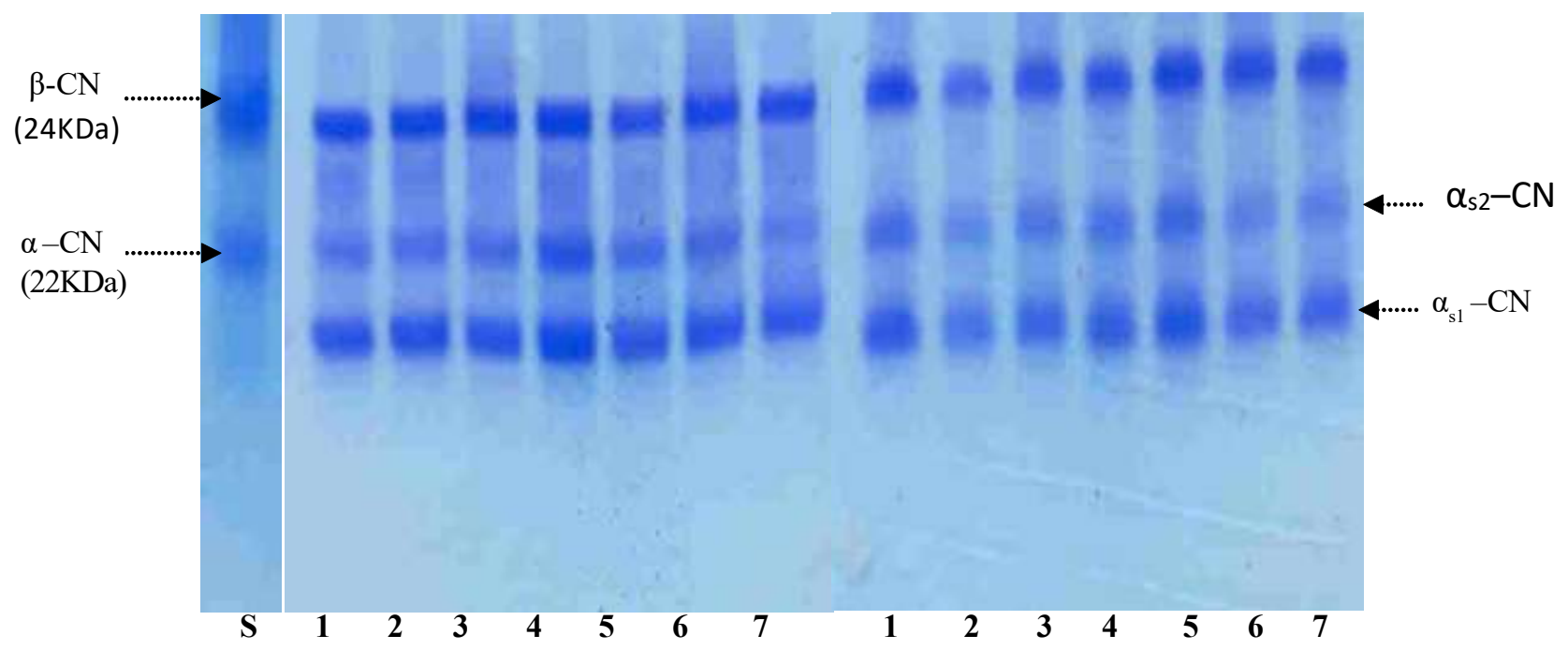

Fig. 4. Urea- Polyacrylamide gel electrophoretograms of processed cheeses: A -Zero day of storage, B-20 th day of storage. SSodium caseinate standard, 1- Control processed cheese 2- Potato incorporated cheese, 3- Peanut incorporated cheese, 4- Inulin incorporated cheese, 5- Potato incorporated cheese with fennel extract, 6- Peanut incorporated cheese with ajwain extract, 7- Inulin incorporated cheese with fennel extra

Casein $(\alpha-\mathrm{CN})$ positions are shown (lane S, Figure 4). All the cheese samples show 3 prominent bands i.e., $\beta$ - Casein, $\alpha_{s 1}{ }^{-}$ Casein and $\alpha_{\mathrm{s} 2}-$ Casein. The cheese samples were made from ripened cheddar cheese where proteolysis of casein has taken place and show the visible bands of $\beta$ - Casein, $\alpha_{\mathrm{s} 1}-$ Casein and $\alpha_{\mathrm{s} 2}-$ Casein. At $20^{\text {th }}$ day of storage no further hydrolysis was observed in control cheese however a decrease in the intensity of $\alpha_{\mathrm{s} 2}$ - Casein $>\alpha_{\mathrm{s} 1}$ - Casein $>\beta$-Casein was observed in the treated samples and maximum decrease was observed in $\mathrm{PO}$ followed by PE (Figure 4B). The decrease in the intensity indicates further proteolysis which must be due to the higher rate of microbial growth in these samples. The higher carbohydrate and moisture content of the potato incorporated cheese might have favored the growth of microbes leading to more proteolysis. This was also confirmed from the tyrosine content of PO which showed higher tyrosine content compared to control and other cheese samples during storage Figure 2(a).

In contrast, POF and PEA showed lower degree of proteolysis. The electrophoretic patterns of cheese samples with and without 


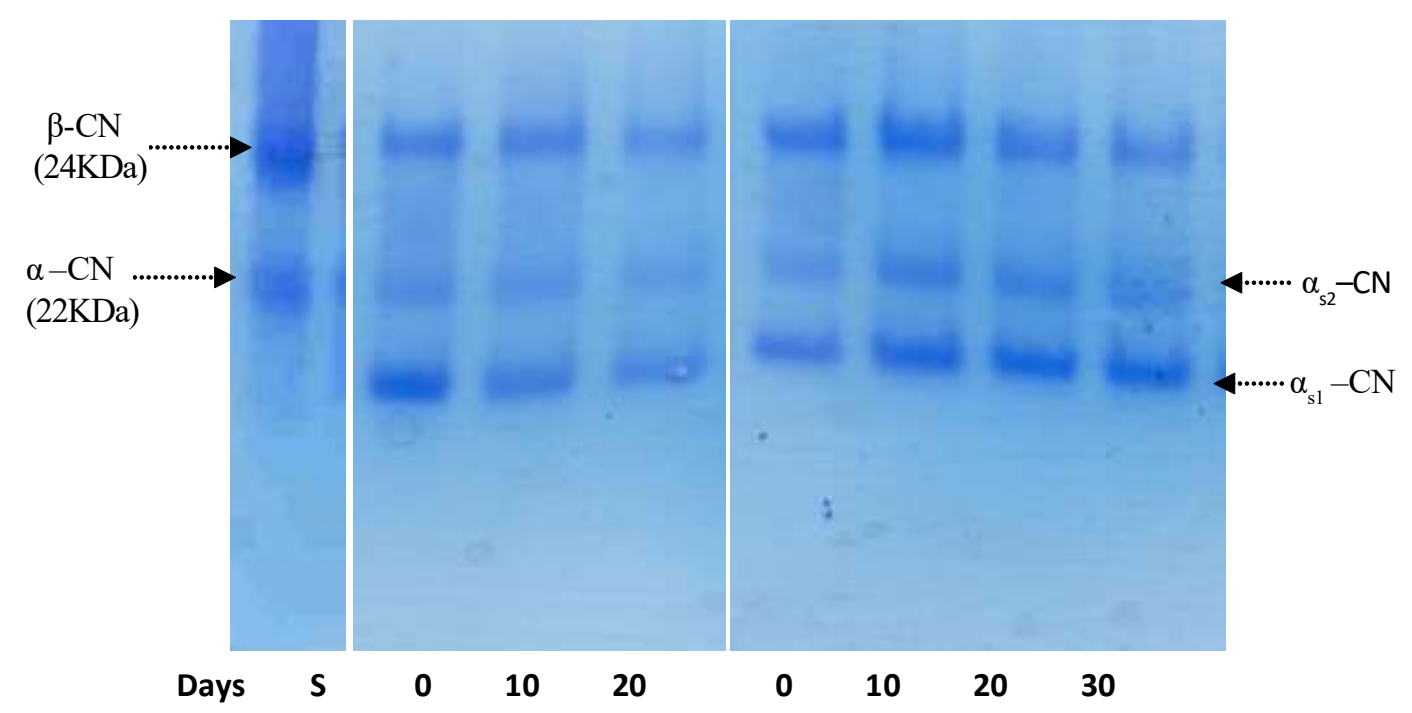

Fig. 5 Urea-Polyacrylamide gel electrophoretograms of Sodium caseinate standard (S), (A) Potato incorporated cheese, (B) Potato incorporated cheese with fennel extract.

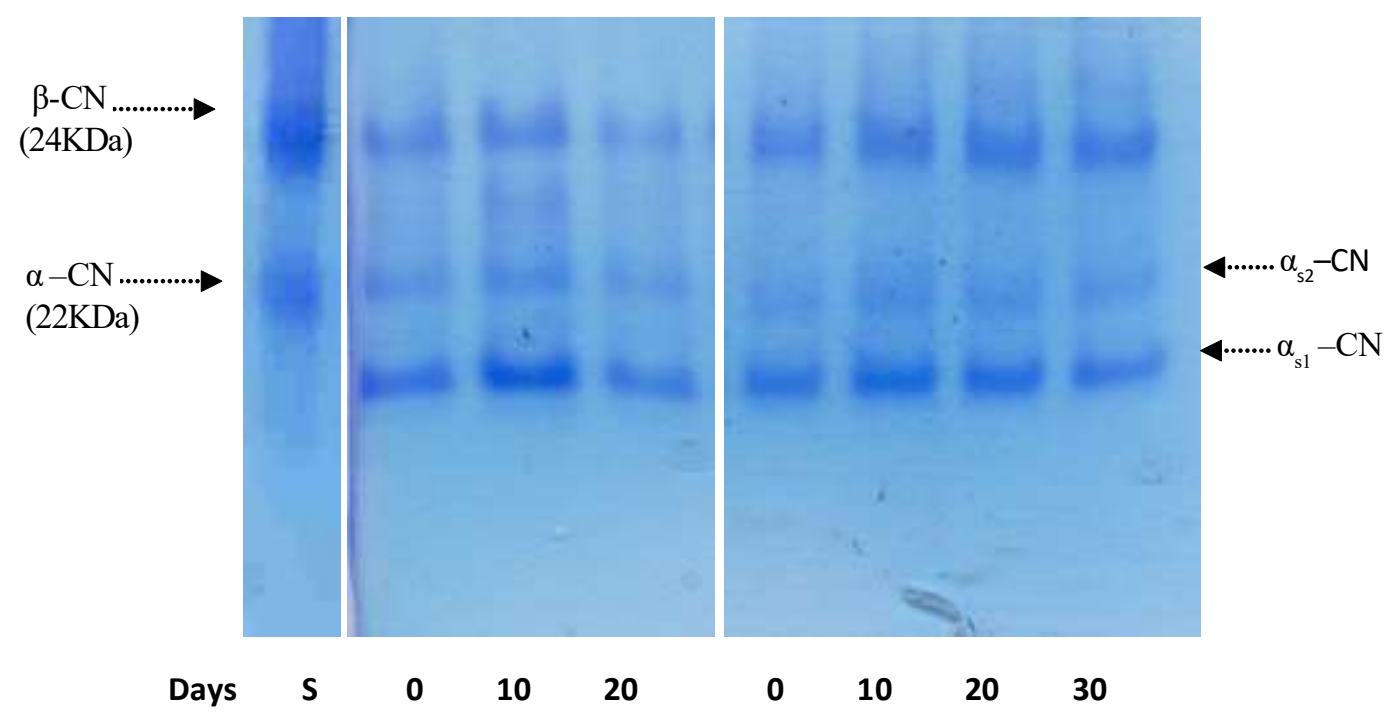

Fig. 6 Urea-Polyacrylamide gel electrophoretograms of Sodium caseinate standard (S), (A) Peanut incorporated cheese, (B)

Peanut incorporated cheese with ajwain extract

spice extracts are shown in Figure 5-6. PO Figure 5(A) showed higher proteolysis than POF Figure 5(B) both at $10^{\text {th }}$ and $20^{\text {th }}$ day of storage. The $\alpha_{\mathrm{s} 2}-\mathrm{CN}$ breakdown was more than $\alpha_{\mathrm{s} 1}-\mathrm{CN}$ and $\beta$ $\mathrm{CN}$ as the intensity of $\alpha-\mathrm{CN}$ became lower than $\beta-\mathrm{CN}$. The higher proteolysis was due to the higher microbial load in PO. The addition of fennel extract to the potato incorporated cheese slowed down the degree of proteolysis to a greater extent as more visible bands are present in POF Figure 5b.

PE showed less proteolysis on $20^{\text {th }}$ day of storage Figure 6(a) whereas, PEA did not show any proteolysis on $20^{\text {th }}$ day of storage Figure 6(b). A slight degradation was observed in PEA on $30^{\text {th }}$ day of storage. IN samples showed minimum proteolysis among all the PCFs and those containing fennel extracts did not show any proteolysis. Therefore, no electrophoretogram of inulin treated sample is shown.

\section{Microbial changes}

\section{Changes in yeast and mould count}

All the processed cheese samples were plated in Potato Dextrose Agar (PDA) to study the yeast and mould counts during storage. Yeast and mould count was found to increase during storage. At $0^{\text {th }}$ day of storage yeast and mould count of $6.66 \mathrm{cfu} / \mathrm{g}$ was maximum in PE followed by $5.0 \mathrm{cfu} / \mathrm{g}$ in PO (Figure 3a). Control processed cheese showed initial yeast and mould count of 3.33 
$\mathrm{cfu} / \mathrm{g}$. Yeast and mould counts increased as the storage progressed and it was found that yeast and mould count of PO and PE increased at a much higher rate as compared to control at $10^{\text {th }}$ and $20^{\text {th }}$ day of storage. Addition of spice extracts was found to slow down the rate of increase in yeast and mould counts. Initial yeast and mould count of $8.33 \mathrm{cfu} / \mathrm{g}$ in PEA increased to 10 $\mathrm{cfu} / \mathrm{g}$ at $20^{\text {th }}$ day of storage (Figure $3 \mathrm{~b}$ ). The rate of increase was lower than in PE wherein it increased from 6.66 to $15 \mathrm{cfu} / \mathrm{g}$ at $20^{\text {th }}$ day of storage. Similar rate of change was observed in POA and INF.

The higher rate of increase in the yeast and mould counts in PE and PO might be due to the carbohydrate content of these cheeses however, lower rate of increase in extract added cheeses might be due to the antimicrobial properties of the extracts which might have suppressed the growth of yeast and moulds during storage thus improving their microbial quality. Similar results were found by Krumov et al. (2010) who reported that the addition of spice extracts (Piper nigrum and Satureja hortensis) improved microbiological quality of processed cheese significantly.

\section{Changes in coliform count}

In the present study, coliforms were found to be absent in all the fresh samples and no coliform growth was observed till the end of storage.

\section{Conclusions}

The addition of aqueous extracts of fennel and ajwain improved the microbial stability of processed cheese foods during storage. As a consequence, these spice extracts increased the shelf life of these products. Moreover, the flavour of non-dairy ingredient added cheeses is better maintained during storage contributing to improved overall consumer acceptability. These spice extracts can be considered to be used in the preservation of cheese. Further, the effect of essential oils from these two spices on the shelf life of cheese can be the next step in this research.

\section{Conflict of interest}

Authors declare no conflict of interest.

\section{References}

Abed KF (2007) Antimicrobial activity of essential oils of some medicinal plants from Saudi Arabia. Saudi J Biol Sci 14: 53-60

Awad S, Hassan AN, Halaweish F (2005) Application of exoploysacchride producing cultures in reduced cheese Cheddar cheese: Composition and proteolysis. J Dairy Sci 8: 4195-4203

Ceylan E, Fung DY (2004) Antimicrobial activity of spices 1. J Rapid Methods Autom Microbiol 12: 1-55

Creamer LK (1991) Electrophoresis in cheese. Bull IDF 261: 14-28

Cusato S, Gameiro AH, Corassin CH, Sant'Ana AS, Cruz AG, Faria JDAF, de Oliveira CAF (2013). Food safety systems in a small dairy factory: Implementation, major challenges, and assessment of systems' performances. Foodborne Pathog Dis 10: 6-12
Deeth HC, Fitzgerald CH (1976) Lipolysis in dairy products: a review. Aust J Dairy Technol 31: 53-64

Dias MAC, Sant'Ana, AS, Cruz AG, José de Assis FF, de Oliveira CAF, Bona E (2012) On the implementation of good manufacturing practices in a small processing unity of mozzarella cheese in Brazil. Food Control 24: 199-205

Guinee TP, Caric M, Kalab M (2004) Pasteurized processed cheese and substitute/imitation cheese products. In: Fox PF, editor. Cheese: chemistry, physics and microbiology. Volume 2: major cheese groups. 3rd ed. London, U.K.: Elsevier Applied Science 349-394

Gyawali R, Ibrahim SA (2012) Impact of plant derivatives on the growth of foodborne pathogens and the functionality of probiotics. Appl Microbiol Biotechnol 95: 29-45

Hayek SA, Gyawali R, Ibrahim SA (2013) Antimicrobial natural products. In A. Mendez-Vilas (Ed.), Microbial pathogens and strategies for combating them: Science, technology and education 2: 910-921

He W, Huang B (2011). A review of chemistry and bioactives of a medicinal spice: Foeniculum vulgare. J Med Plant Res 5: 3595-3600

Houghtby GA, Maturin LJ, Koenig EK (1993) Microbiological count methods. In: "Standard methods for the examination of dairy products". Chapter 6, Sixteenth Edn. (Ed. Marshall RT), Washington: American Public Health Association, pp. 213-246

Hussein FSE, Ibtisam M, El Zubeir M, Abdelaziz AF (2011) Quality Evaluation of Imported and Locally Produced Processed Cheese in Sudan. Jordan J Biol Sci 4: 231-236

Kapoor R, Metzger LE (2008) Process cheese: Scientific and technological aspects-A review. Compr Rev Food Sci Food Saf 7: 194-214

Meyer A (1973) Processed cheese manufacture. London, U.K.: Food Trade Press Ltd

Morsi NM (2000). Antimicrobial effect of crude extracts of Nigella sativa on multiple antibiotics-resistant bacteria. Acta Microbiologica Polonica 49: 63-74

Nagalakshmi S, Shakaracharya NB, Pura Naik J, Rao JML (2000) Studies on chemical and technological aspects of ajowan (Trachyspermum ammi (L.) Syn. Carum copticum Hiern) seeds. J Food Sci Technol 37: $277-281$

Purohit P, Bohra A (2002) Antifungal activity of various spice plants against phytopathogenic fungi. Adv Plant Sci 15: 615-618

Rafiq SM, Ghosh BC (2017) Texture, meltability, color and sensory properties of processed cheese as affected by the addition of inulin. Indian J Dairy Sci 70:658-664

Rafiq SM, Ghosh BC (2017) Effect of peanut addition on the fatty acid profile and rheological properties of processed cheese. J Food Process Technol8: 690

Rafiq SM, Ghosh BC (2017). Effect of potato incorporation on the physico-chemical, textural and sensory properties of processed cheese. J Food Meas Charact 11: 776-780

Renuka V, Ramasamy D, Kumar DV (2016) Fortification of omega-3 fatty acids in processed cheese spread. Int J Sci Environ Technol 5: 2557-2565

Salek RN, Cerníkova M, Nagyova G Kuchar D, Bacova H, Minarcikova L, Bunka F (2015) The effect of composition of ternary mixtures containing phosphate and citrate emulsifying salts on selected textural properties of spreadable processed cheese. Int Dairy J 44: 37-43

Samples DR, Richter RL, Dill CW (1984) Measuring proteolysis in cheddar cheese slurries: comparison of hull and trinitrobenzene sulfonic acid procedures. J Dairy Sci 67: 60-63

Tajkarimi M, Ibrahim S, Cliver D (2010) Antimicrobial herb and spice compounds in food. Food Control 21: 1199-1218

Thakur N, Sareen N, Shama B, Jagota K (2013) Studies on in vitro antifungal activity of Foeniculum vulgare Mill. against spoilage fungi. Global J Bio Sci Biotechnol 2: 427-430 